\title{
DET ERMINATION \\ OF DYNAMIC CHARACTERISTICS \\ OF AUSTENITIC STEEL TO BE UTILIZED IN FEM SIMULATION AND ITS VERIFICATION
}

\author{
Bogdan Szturomski, Krzysztof Świątek, Wojciech Jurczak
}

Polish Naval Academy, Faculty of Mechanical and Electrical Engineering, Śmidowicza 69 Str., 81-127 Gdynia, Poland; e-mail: \{b.szturomski; k.swiatek; w.jurczak\}@amw.gdynia.pl

\begin{abstract}
This paper presents the dynamic mechanical properties of austenitic steel with improved durability, which is used in the construction of hulls of minesweepers, mine destroyers, submarines and other naval vessels. Dynamic tensile tests performed on the steel samples using a rotary hammer with a strain rate of up to $1000 \mathrm{~s}-1$ allowed determination of elastic-plastic characteristics of the material in the form of a polynomial of Johnson-Cook constitutive model, taking into account the influence of strain rate and temperature. A characteristic of this type is utilized in numerical calculations in the CAE software. The obtained characteristics were experimentally verified by bending tests of flat samples with a drop-weight type impact hammer. Simultaneously numerical calculations were performed in order to compare the deformation state.
\end{abstract}

Key words:

dynamic characteristics of material, drop-weight type impact hammer, rotary hammer, Johnson-Cook constitutive model.

Research article

(C) 2018 Bogdan Szturomski, Krzysztof Świątek, Wojciech Jurczak This is an open access article licensed under the Creative Commons Attribution-NonCommercial-NoDerivatives 4.0 license (http://creativecommons.org/licenses/by-nc-nd/4.0/) 


\section{INTRODUCTION}

Continuous improvement in computing power has a direct influence on the development of computer techniques and the computer aided engineering (CAE) software employed for mechanical analysis of structures. Advanced algorithms of the finite element method (FEM) in a dynamic explicit approach makes it possible to analyse moving objects, taking into account the forces of inertia where a fundamental equation of motion is described by the formula $[1,2,7,10]$ :

$$
M \ddot{U}+\boldsymbol{C} \dot{U}+K \boldsymbol{U}=\boldsymbol{F}
$$

where:

M - inertia matrix;

C - damping matrix;

$\boldsymbol{K} \quad$ - structural rigidity matrix;

$\boldsymbol{F} \quad-$ load vector;

$\boldsymbol{U}, \dot{\boldsymbol{U}}, \ddot{\boldsymbol{U}}-$ displacement, velocity and acceleration vectors.

FEM solves the equations of motion using direct integration methods, also called step by step methods, which engulf central difference, Houbolt, Newmark, Euler and Wilson methods [3-5, 7, 8].

Recent years have brought a progress in algorithms allowing analysis of highly dynamic processes. They are applied in automotive, aerospace and military industry and utilized for simulation of such hazards as the collision of objects, punch-through of armour with bullet, detonation wave impact on vehicles, ship hull impact of pressure wave originating from non-contact explosion of floating mine, etc. shown fig. 1.

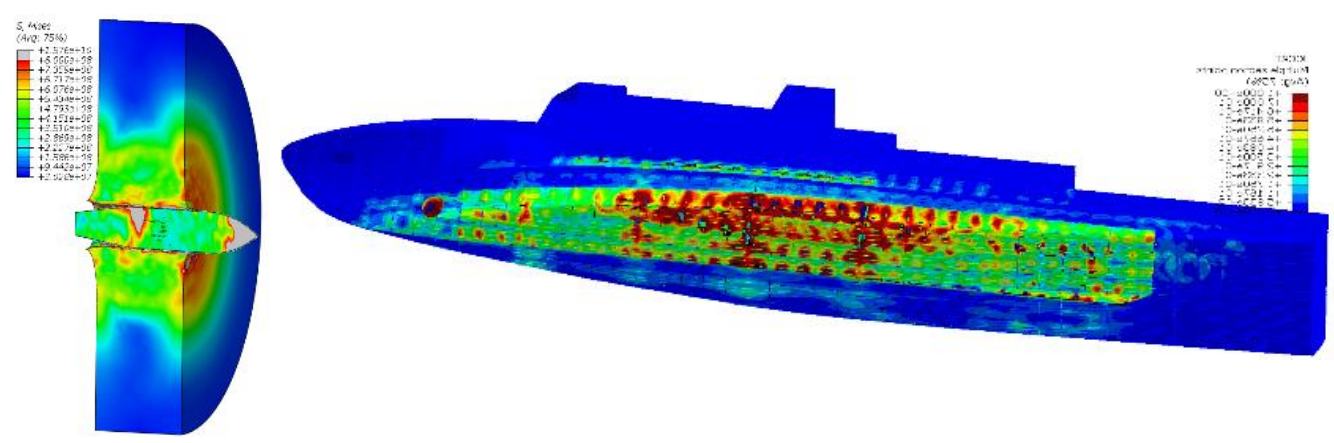

Fig. 1. Examples of highly dynamic processes: punch-through of steel armour with bullet, ship hull impact of pressure wave originating from mine explosion 


\section{DYNAMIC CHARACTERISTICS OF AUSTENITIC STEEL}

The aforementioned problems are highly non-linear due to load character, construction material behaviour, significant deformation of structure and other factors taken into account during the analysis, for instance contact forces between the colliding elements of the structure. Then an exemplary equation of motion takes the form [11]:

$$
\begin{gathered}
\boldsymbol{M}(\boldsymbol{U}) \ddot{\boldsymbol{U}}+\boldsymbol{C} \dot{\boldsymbol{U}}+\boldsymbol{K}\left(\boldsymbol{U}, \dot{\boldsymbol{\varepsilon}}, \boldsymbol{\varepsilon}_{\text {failure }}\right) \boldsymbol{U}=\boldsymbol{F}\left(t, m, v_{\mathrm{c}}, \alpha, \mathrm{BC}, C_{\mathrm{int}}, \mathrm{A}, \mathrm{B}, \ldots\right) \\
\boldsymbol{U}\left(t_{0}\right)=\boldsymbol{U}_{0} \quad \dot{\boldsymbol{U}}\left(t_{0}\right)=\dot{\boldsymbol{U}}_{0}
\end{gathered}
$$

where:

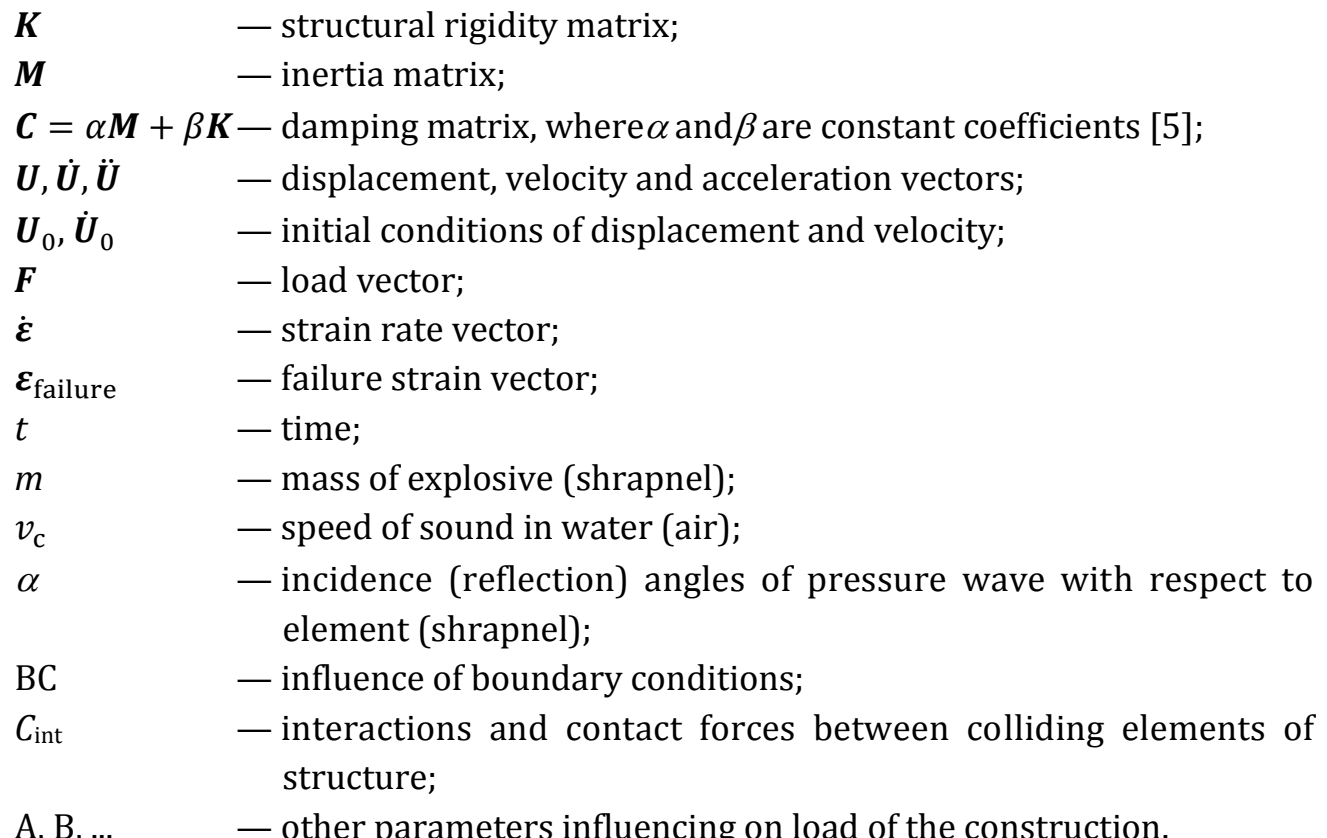

The above parameters of this model are defined based on static tensile test and Hopkinson's or Taylor's tests. For the strain rate up to $1000 \mathrm{~s}-1$ these parameters can be determined with dynamic tensile test using a rotary hammer.

This paper presents dynamic characteristics obtained with the use of the rotary hammer for austenitic steel 1.3964 subjected to heat treatment W72387 (hot rolled, solution annealed, pickled) according to the standard EN 10029-11. Austenitic steels are applied in shipbuilding industry. Due to their enhanced durability and non-magnetic properties austenitic steels are used for construction of hulls of minesweepers, 
mine destroyers, submarines and other naval vessels. The rotary hammer (fig. 2) is a tensile testing machine, in which one end of a sample (fig. 3) is fixed. The sample is subjected to dynamic tension via gearing of its other end with a tooth moving with a velocity $v$ due to rotational speed of the hammer's flywheel.
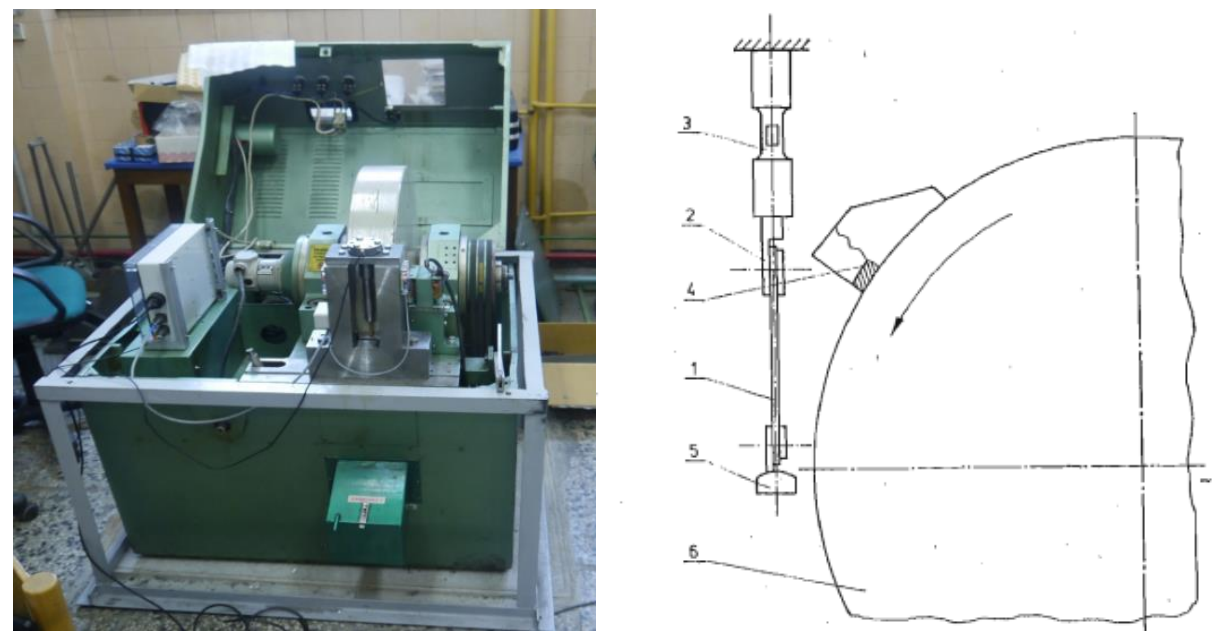

Fig. 2. Scheme of tensile test using rotary hammer: $1-$ sample, $2-$ upper holder, 3 - dynamometer, 4 - tooth, 5 - lower holder, 6 - flywheel

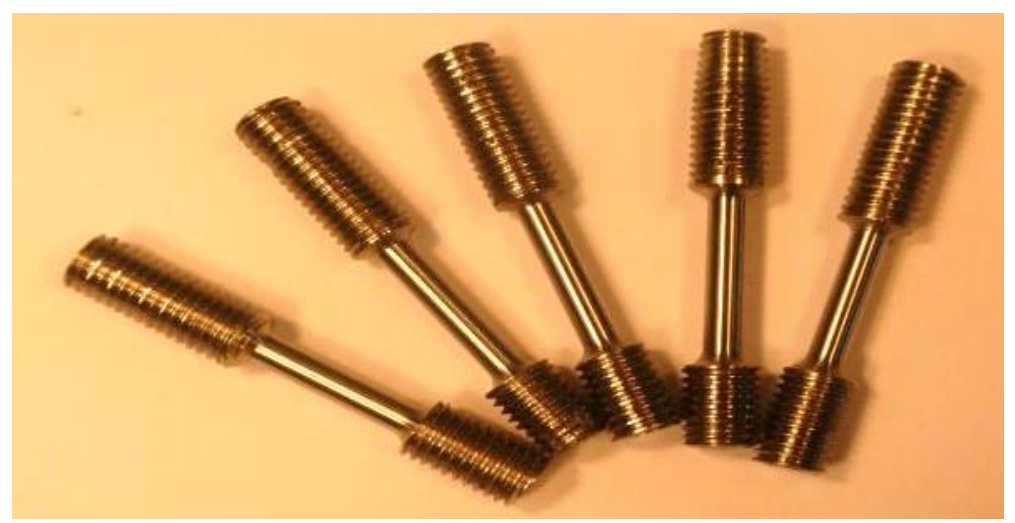

Fig. 3. A photo of selected samples prior to investigation using rotary hammer

Having obtained the results of static tensile test performed on a MTS tensile testing machine and the results of dynamic tensile test carried out with the rotary hammer for the strain rate up to $1000 \mathrm{~s}-1$, a characteristics of steel 1.3964 was determined (fig. 4). Detailed methodology of determination of dynamic characteristics and Johnson-Cook equation's coefficients is provided in the paper [6]. 
A rotary hammer with a strain rate of up to $1000 \mathrm{~s}-1$ was used and a characteristic of steel 1.3964 was determined (fig. 4). Detailed methodology of determination of dynamic characteristics and Johnson-Cook equation's coefficients [6] is provided in the paper [11].

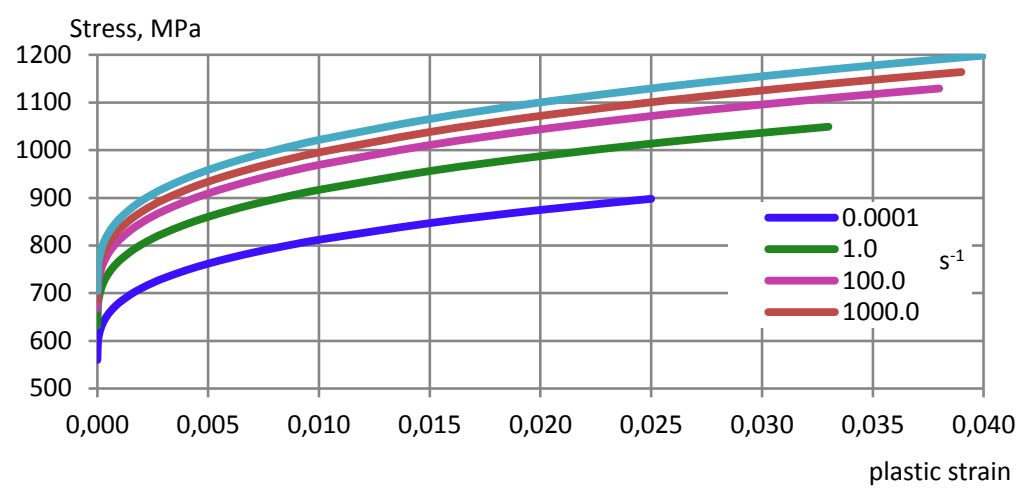

Fig. 4. Characteristics of steel 1.3964 for different strain rates: $A=550 \mathrm{MPa}, B=1100 \mathrm{MPa}, n=0.32, m=1.13, \theta_{\mathrm{op}}=1793 \mathrm{~K}, \theta_{0}=293.15 \mathrm{~K}, C=0.006, \dot{\varepsilon}_{0}=0.0001 \mathrm{~s}^{-1}$; the remaining parameters are as follows:

young's modulus $-E=2.1 \cdot 10^{5} \mathrm{MPa}$, poisson ratio $-v=0.3$, static yield stress $-R_{\mathrm{e} \text { Stat }}=560 \mathrm{MPa}$, static ultimate strength $-R_{\mathrm{m} \text { Stat }}=880 \mathrm{MPa}$

Dynamic characteristics of steels or other materials determined for the CAE simulation must be verified experimentally. A series of bending tests of flat samples made of previously investigated austenitic steel was carried out using a drop-weight type impact hammer. In this test a flat steel sample was struck with a rigid ram having a different mass - from 10 to $30 \mathrm{~kg}$ and different velocity - from 1 to $7 \mathrm{~m} / \mathrm{s}$ (fig. 5).

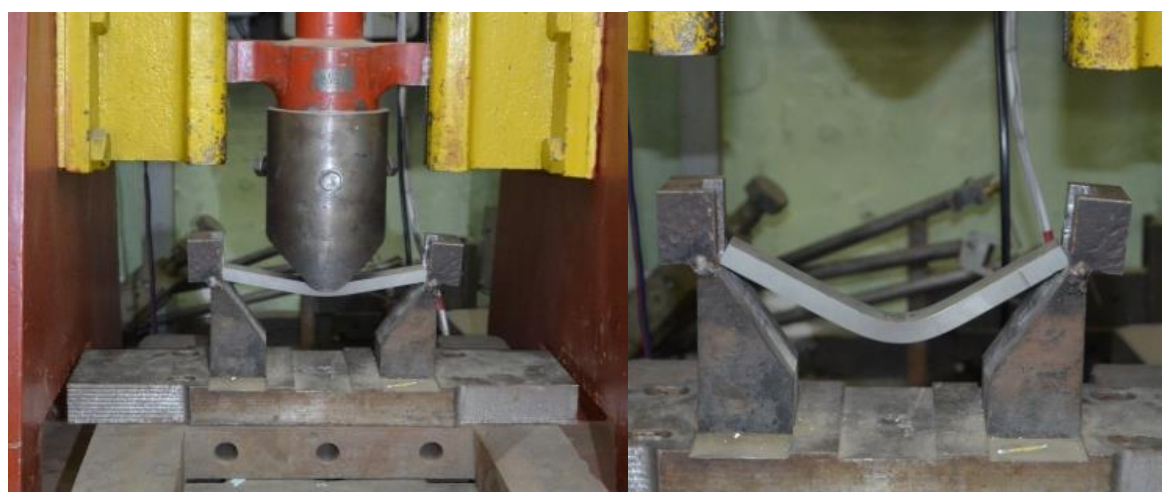

Fig. 5. Bending test of flat sample using drop-weight type impact hammer 
Simultaneously, a dynamic explicit type numerical simulation of analogous task was performed using the CAE software solving the following equilibrium equation [11]:

$$
\boldsymbol{M}(\boldsymbol{U}) \ddot{\boldsymbol{U}}+\boldsymbol{C} \dot{\boldsymbol{U}}+\boldsymbol{K}(\boldsymbol{U}, \dot{\boldsymbol{\varepsilon}}) \boldsymbol{U}=\boldsymbol{F}\left(m, v_{C}, \mathrm{BC}, C_{\mathrm{int}}\right)
$$

where

$v_{\mathrm{c}}$ - speed of sound in water (air).
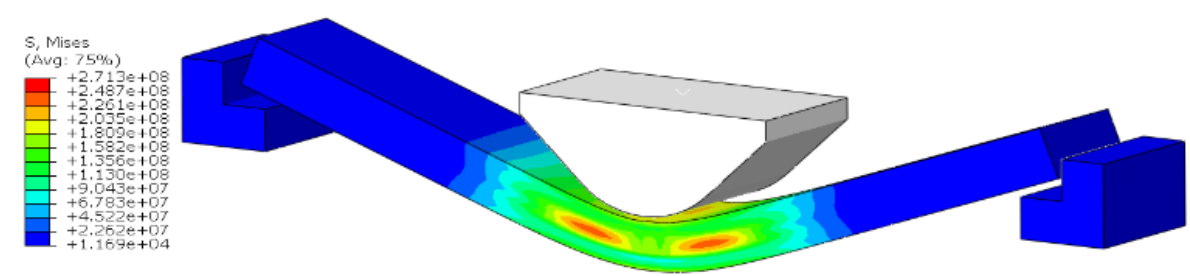

Fig. 6. CAE simulation of bending test on a flat sample using drop-weight type impact hammer

Material characteristics were subjected to numerous corrections and a number of simulations were performed for different ram mass and ram impact velocity searching for the best convergence with the experiment. A comparison of the results is presented in tab. 1 .

Tab. 1. Comparison of results from experimental bending test and CAE simulation

\begin{tabular}{|c|c|c|c|c|}
\hline No. & $\begin{array}{c}\text { Ram height } \\
\mathrm{m}\end{array}$ & $\begin{array}{c}\text { Initial length } \\
\mathrm{H}, \mathrm{mm}\end{array}$ & $\begin{array}{c}\text { Permanent bending } \\
\text { upon drop-weight type } \\
\text { impact hammer }\end{array}$ & $\begin{array}{c}\text { Permanent bending } \\
\text { upon numerical } \\
\text { simulation } \\
\text { mm }\end{array}$ \\
\hline 1 & 0,5 & 97 & 3,8 & 4,0 \\
\hline 2 & 1,5 & 97 & 21,6 & 23,4 \\
\hline 3 & 2,0 & 97 & 31,4 & 34,6 \\
\hline
\end{tabular}

\section{CONCLUSIONS}

The determined material characteristics in the form of JC material model for austenitic steel, for a strain rate of up to $1000 \mathrm{~s}-1$ can be utilized to simulate highly dynamic processes such as the collision of objects, analysis of armour resistance to machine gun fire or analysis of a structure subjected with a pressure 
wave originating from an explosion. The characteristics were acquired based on relatively inexpensive laboratory investigations including quasi-static tensile test on the MTS tensile testing machine and dynamic test with the rotary hammer for the strain rate up to $1000 \mathrm{~s}-1$. The FEM simulation of dynamic bending of the flat sample using the drop-weight type impact hammer, in which the aforementioned characteristics were implemented in the form of a JC material model, provided satisfactory results compared to the experiment. As far as evaluation of structure resistance to impact is concerned, a model of material is only one of many important elements, which have an influence on the results obtained.

\section{REFERENCES}

[1] Abaqus 6.12. Theory Manual, Simulia, Dassault Systemes, pdf documentation, 2012, [online], http://жбк.рф/library/abaqus_doc/Documentation/docs/v6.12/pdf_books/CAE.pdf [access 14.04.2918].

[2] AUTODYN ${ }^{\circledR}$ Explicit Software for Nonlinear Dynamics, SPH User Manual \& Tutorial, Revision 4.3, Century Dynamics 2005 [online], http://oss.jishulink.com/caenet/forums/upload/2008/01/27/ 7928171817357.pdf [access 14.04.2918].

[3] Bathe K. J., Finite element procedures, Prentice-Hall, Englewood Cliffs, New Jersey 1996.

[4] Bathe K.-J., Wilson E. L., Numerical methods in finite element analysis, Prentice-Hall, Englewood Cliffs, New Jersey 1976.

[5] Houbolt J. C., A recurrence matrix solution for the dynamic response of elastic aircraft, 'Journal of the Aeronautical Sciences', 1950, Vol. 17, pp. 540-550.

[6] Johnson G. R., Cook W. H., A constitutive model and data for metals subjected to large strains, high strain rate, and temperatures, International Symposium on Ballistics, Hague 1983.

[7] Kacprzyk Z., Rakowski G., Metoda elementów skończonych w mechanice konstrukcji, Publ. Warsaw University of Technology, Warszawa 2005 [Finite element analysis in mechanics of structures — available in Polish].

[8] Kleiber M., Metoda elementów skończonych w nieliniowej mechanice kontinuum, PWN, Warszawa 1985 [Finite element analysis in non-linear continuum mechanics — available in Polish].

[9] MSC MARC, Documentation: Theory and user information, MSC Software Corporation, 2001.

[10] Szturomski B., Inżynierskie zastosowanie MES w problemach mechaniki ciała stałego na przykładzie programu ABAQUS, Publ. Polish Naval Academy, Gdynia 2013 [Engineering application of finite element analysis to the problems of mechanics of solids on the example of the ABAQUS software — available in Polish].

[11] Szturomski B., Modelowanie oddziaływania wybuchu podwodnego na kadłub okrętu w ujęciu numerycznym, Publ. Polish Naval Academy, Gdynia 2016 [Modelling of underwater explosion impact on ship hull using numerical approach — available in Polish]. 


\section{WYZNACZAN I E \\ CHARAKTERYST YKI DYNAMICZNEJ \\ STALI AUSTENITYCZNEJ NA POTRZEBY SYMULACJI MES I JEJ WERYFIKAC JA}

\section{STRESZCZENIE}

W artykule przedstawiono dynamiczne właściwości mechaniczne stali austenitycznej o podwyższonej wytrzymałości, która jest wykorzystywana do budowy kadłubów trałowców, niszczycieli min, okrętów podwodnych oraz innych jednostek wojennych. Na podstawie dynamicznego rozciągania próbek na młocie rotacyjnym w zakresie prędkości odkształcenia do $1000 \mathrm{~s}-1$ opracowano sprężysto-plastyczną charakterystykę materiału w formie wielomianu $\mathrm{w}$ postaci modelu konstytutywnego Johnsona-Cooka uwzgledniającego prędkość odkształcenia i wpływ temperatury. Charakterystyka tego typu wykorzystywana jest w obliczeniach numerycznych w programach CAE. Otrzymaną charakterystykę zweryfikowano, wykonując eksperyment udarowego zgięcia płaskownika na młocie opadowym, dla którego równolegle wykonano obliczenia numeryczne, porównując stan deformacji.

\section{Słowa kluczowe:}

dynamiczna charakterystyka materiału, młot rotacyjny, młot opadowy, model konstytutywny Johnsona-Cooka.

Article history

Received: 27.03.2018

Reviewed: 09.06 .2018

Revised: $\quad 25.06 .2018$

Accepted: $\quad 26.06 .2018$ 